\title{
QUESTÕES FEMININAS E RACIAIS EM MOÇAMBIQUE E NO BRASIL ATRAVÉS DOS OLHARES DE PAULINA CHIZIANE E CONCEIÇÃO EVARISTO
}

Vera Tatiana dos Reis Monteiro Gomes é Mestra e Doutoranda em Literatura, Cultura e Contemporaneidade Pela PUC-Rio. E-mail: veramonteiro8@hotmail.com

Resumo

$\mathrm{O}$ artigo relaciona os olhares da moçambicana Paulina Chiziane e da brasileira Conceição Evaristo, através das personagens dos romances Niketche, uma história de poligamia e Ponciá Vicêncio, investigando, ainda, a postura das próprias autoras como ativistas do "feminino", por meio de palestras, entrevistas e conferências das quais participaram, apontando zonas de contato e de divergência entre as questões femininas e raciais por elas abordadas.

\begin{abstract}
Résumé
L'article concerne les regards de Paulina Chiziane et de Conceição Evaristo, à travers les personnages de romans Niketche, une histoire de polygamie et Ponciá Vicêncio, enquête également la position des auteurs eux-mêmes en tant que militants du «féminin», à travers des conférences, des interviews et des conférences auxquelles assistent, en pointant zones de contact et de divergence entre les questions féminines et raciales abordées par eux.
\end{abstract}

Apesar dos avanços conquistados pelas mulheres no século XX, tanto em Moçambique como no Brasil, a cultura patriarcal continua influenciando os complexos modos de constituição das relações sociais e políticas nos dois países, em diferentes níveis e formas, metamorfoseando-se ao longo da história, mas carregando a sua herança e impedindo que a mulher transponha de maneira mais ampla a posição de subalternidade que o patriarcado impôs.

Diante desse fato, o artigo busca discutir de que maneira a distinção de poderes e direitos entre homens e mulheres subsiste e quais são as principais situações da vida social, econômica, política e afetiva nas quais se manifesta, partindo de uma abordagem relacional entre o olhar de duas escritoras, a moçambicana Paulina Chiziane e a brasileira Conceição Evaristo, através das personagens dos romances Niketche, uma história de poligamia e Ponciá Vicêncio, investigando, ainda, a postura das próprias autoras como ativistas do "feminino".

A opção pelas duas escritoras se deveu ao desejo de comparar duas obras contemporâneas, de duas escritoras negras, nascidas em dois países de colonização portuguesa, um na África e outro inserido no contexto da herança escravocrata da africanidade diaspórica, a fim de ler, comparativamente nos romances, as resultantes contemporâneas do processo colonial presentes nas relações raciais e, principalmente, de gênero nos dois países. Os nomes de Chiziane e Evaristo foram escolhidos pelo comprometimento com a denúncia social às relações de poder e dominação sexistas e racistas presentes nos seus países e pelo reconhecimento, já em âmbito internacional, de suas obras, tendo Chiziane recebido por Niketche o prêmio José Craveirinha, em 2003, e Evaristo recebido o prêmio Portugal Telecom, em 2009, com a antologia poética Poemas da Recordação e Outros Movimentos.

Dentro dessa lógica de engajamento, considerou-se que os romances mais importantes para este estudo dentre os publicados pelas duas autoras são os que atingiram maior repercussão no público leitor e na crítica, nos seus países e no exterior, que são Niketche, um dos seis romances de Chiziane, publicado em 2002 e premiado em 
2003, a única obra da escritora publicada no Brasil, e Ponciá Vicêncio, o primeiro dos dois romances escritos por Evaristo, publicado em 2003.

Como se trata de uma escrita de mulheres negras, cuja voz foi duplamente sufocada ao longo da história de ambos os países, essa literatura pode ser entendida como um ato de insubordinação, que, além de criticar as situações de exclusão racial e de gênero, propicia uma forma de autoinscrição no mundo. Em outras palavras, a literatura feita pelas mulheres negras permite que elas saiam da posição de objetos da história, para se constituírem como sujeitos da produção textual, inscrevendo nela as suas vozes, a partir da perspectiva do seu grupo. Nesse sentido, cabe citar as palavras de Evaristo:

Escrever pressupõe um dinamismo próprio do sujeito da escrita, proporcionando-lhe a sua autoinscrição no interior do mundo. E, em se tratando de um ato empreendido por mulheres negras, que historicamente transitam por espaços culturais diferenciados dos lugares ocupados pela cultura das elites, escrever adquire um sentido de insubordinação (EVARISTO apud COSTA 1996, p. 20).

É necessário assinalar que além das duas autoras terem uma trajetória de militância política e de construírem seus romances como forma de denúncia, partiu-se do entendimento de que há um estreito entrelaçamento entre história e literatura, motivo pelo qual considera as vozes das personagens dos romances como testemunhos das experiências do grupo a que pertencem. Segundo a pesquisadora Renata Jesus da Costa, citando Edward W. Said, os escritores e as escritoras "estão profundamente ligados à história de suas sociedades, moldando e moldados por essa história e suas experiências sociais em diferentes graus" (SAID apud COSTA, 2007, p. 28).

Tanto ao historiador quanto ao romancista cabem construir a narrativa histórica através da imaginação. O historiador se utiliza de documentos que fornecem pistas de acontecimentos que "outrora foram reais e vivos", mas que ao serem recriados, criticados e recontados por ele, são transformados por sua mente. "A história se serve, de algum modo, da ficção para reconfigurar o tempo e, por outro lado, a ficção se vale da história com o mesmo objetivo" (RICOEUR apud COSTA, 2007, p. 28).

Conclui, assim, a pesquisadora, que as novas perspectivas no campo da história, tanto do ponto de vista metodológico quanto do ponto de vista teórico, reforçam a existência de um entrelaçamento entre história e literatura. A obra literária como "testemunho histórico" é vista como uma das possibilidades para pesquisar o passado, sem deixar de considerar que foram produzidas por atores historicamente situados em contextos socialmente definidos.

Nesse sentido, a literatura de Chiziane, considerada a primeira romancista moçambicana, pode ser entendida como "testemunho histórico", ainda mais porque seus enredos são construídos a partir de narrativas que a autora diz, em entrevista à TV Brasil, ${ }^{1}$ ter ouvido de outras pessoas, através de conversas compartilhadas com mulheres à noite, na beira das fogueiras, articulando rememoração a uma prática que remonta à tradição oral africana. Na citada entrevista, a autora revela, ainda, que sofreu

\footnotetext{
${ }^{1}$ Entrevista Paulina Chiziane: Disponível em: http://www.youtube.com/watch?v=ZH4pfDfToSg. Acesso em 17.10.2013, às 00:00:57. 
preconceito por parte dos escritores moçambicanos, tendo sido mal recebida no meio literário de seu país e taxada pejorativamente de feminista, por privilegiar questões relativas às mulheres.

No caso do Brasil, até as décadas iniciais do século XX, como esclarece Antonio Candido, as ciências humanas e naturais não se desenvolveram no mesmo ritmo que as letras ou o direito, razão pela qual a literatura contribuiu com eficácia maior do que se imagina para a formação de uma consciência nacional. Isso fez com que o pensamento da burguesia se desenvolvesse sob influência predominantemente literária e não sob influxos científicos, filosóficos ou técnicos. A partir do século XIX, parcela da literatura se constituiu como uma linha de ensaio em que se combinava imaginação e observação, ciência e arte, funcionando como elemento de ligação entre a pesquisa científica e a criação literária. Havia a interferência da literatura na tendência sociológica e a recíproca dessa contaminação também é verdadeira (CANDIDO, 2010, p 138 -140).

Todavia, os escritores canônicos eram homens, brancos e pertencentes às classes abastadas, refletindo o "ponto de vista" dos dominadores e incutindo no imaginário social imagens estereotipadas sobre o negro, o índio e a mulher. Nesse contexto, a "literatura de insubordinação" das mulheres negras, além de herdeira desta familiaridade entre literatura e confronto com realidade social do país, é fundamental para que venham se autoinscrever na história, assumindo o lugar de fala, registrando-se como sujeitos e deslocando os discursos em que o negro e a mulher aparecem como o "outro".

Para assumir o lugar de sujeito da fala e se autoinscrecer na história, as duas autoras traçaram um caminho de intensa luta, tanto no nível pessoal como enquanto ativistas das questões femininas e raciais. Diante disso, o interesse deste artigo é desenvolver uma análise contrastiva das trajetórias das duas autoras, comparando, ainda, as trajetórias pessoais das autoras com as das personagens dos seus romances.

Iniciamos nossos estudos pesquisando as trajetórias pessoais das duas autoras, a fim de ressaltar que elas representam um contingente de vozes silenciadas por séculos, especialmente as das mulheres negras. Enquanto ativistas, encarnam o perfil do escritor contemporâneo, por facilitarem trocas culturais, atuando como mediadoras, através das suas escritas provocativas sobre o cotidiano. As autoras atendem, assim, às demandas da literatura contemporânea pela democratização e pelo multiculturalismo contra perspectivas hegemônicas ocidentais, intervindo nos espaços público e social através da força conscientizadora e mobilizadora das suas escritas.

Além de considerar as trajetórias pessoais das autoras e as suas escritas mobilizadoras nos dois romances, analisamos suas posturas enquanto ativistas, por meio de palestras, entrevistas, colóquios e conferências das quais participaram, verificando pontos de contato e de divergência entre as questões femininas e raciais por elas abordadas.

Feitos esses esclarecimentos, comecemos pela autora brasileira, Maria da Conceição Evaristo de Brito, que nasceu em 1946, na cidade de Belo Horizonte, sendo a segunda filha de uma família de nove irmãos. Sua mãe, Joana Josefina Evaristo Vitorino, e sua tia falecida, Maria Filomena da Silva, transmitiram a Evaristo a paixão 
por "contar e ouvir histórias", o que gerou, para ela, a necessidade da escrita desde cedo (EVARISTO, 2006, p. 167). A escritora conciliou seus estudos com a profissão de empregada doméstica até completar o normal, aos vinte e cinco anos. ${ }^{2}$ Em 1971, concluiu o ensino normal no Instituto de Educação de Minas Gerais e em 1973, mudouse para o Rio de Janeiro, prestou concurso e ingressou no magistério público. Deu prosseguimento aos seus estudos, cursando a faculdade de Letras (Português-Literatura) na UFRJ. Posteriormente, obteve o título de Mestre em Literatura Brasileira pela PUCRio e de Doutora em Literatura Comparada pela UFF (EVARISTO, 2006, p. 167).

Em entrevista concedida à TV Brasil $^{3}$ - programa 3 a 1 - a escritora revela que escreve desde criança e que seu gosto pela escrita começa com a literatura oral em sua família, que como uma boa família mineira, é contadora de "casos". Isso a teria despertado tanto para a leitura, como para a escrita.

Nesse aspecto, Evaristo se aproxima da escritora moçambicana Paulina Chiziane, que também tomou gosto pela escrita através da literatura oral, das histórias contadas à volta das fogueiras por sua avó. Segundo a escritora, também em entrevista à TV Brasil $1^{4}$, programa 3 a 1 - "as histórias à beira das fogueiras são surpreendentes porque são contadas e recontadas, mas sempre são uma história diferente”. Conta, ainda, que sua avó concedia "prêmios de bom comportamento" pelo dia ou pela semana, e que esse prêmio era ser um personagem bom na história.

Quanto à inspiração para escrever, Evaristo revela, no programa Imagem da Palavra $^{5}$ - da Redeminas TV - que é a vida, o mundo, que oferecem a matéria para que ela escreva. Por isso, criou o termo "Escrivivência", para falar dessa escrita, nascida da observação da vida, termo utilizado também para nomear seu blog.

Evaristo diz que adora perguntar para as pessoas fatos que ocorreram com elas e que, muitas vezes, enquanto as pessoas estão contando um fato, ela já o está escrevendo mentalmente. Diz que quando se retira pra escrever, já colheu "tudo lá fora, ou lá fora ou aqui dentro". E assim, define a sua construção narrativa, através de uma frase que abre o programa: "Entre o acontecimento e a narração do fato, alguma coisa se perde e outra se acrescenta".

No V Colóquio Mulheres em Letras ${ }^{6}$, da UFMG, realizado em 20 de abril de 2013, Evaristo fala novamente do termo Escrivivência, explicando que quando ela cria, o pano de fundo é a existência, a vida. Pode ser a vida do outro que a contaminou, ou o que ela própria viveu diretamente ou indiretamente. A autora diz que sua literatura é contaminada pela vida real e que deseja escrever ficção como se estivesse escrevendo a

\footnotetext{
2 Disponível no blog: http://nossaescrevivencia.blogspot.com.br/search/label/videos, acesso em 19.09.2013, às 20:40:37.

3 Entrevista para TV Brasil, Evaristo: https://www.youtube.com/watch?v=UKyB7b-zX4s. Acesso em 22.09.2013, às 21:19:34.

${ }^{4}$ Entrevista para a TV Brasil, Chiziane: https://www.youtube.com/watch?v=ZH4pfDfToSg. Acesso em 23.09.2013, às 00:37:42.

5 Disponível no blog http://nossaescrevivencia.blogspot.com.br/search/label/videos. Acesso em 19.09.2013, às 20:40:37.

6 Disponível no blog http://nossaescrevivencia.blogspot.com.br/search/label/videos. Acesso em 19.09.2013, às 20:45:48.
} 
verdade, mesmo porque entende que o seu lugar de enunciação é esse lugar da vida real que ela experimenta de uma forma ou de outra, isto é, através da sua experiência ou da experiência do outro.

Cabe ressaltar a observação que Evaristo faz sobre os estereótipos que a literatura brasileira reproduzia sobre os negros. Segundo ela, em entrevista já citada, concedida à TV Brasil, é essa visão crítica que a ajuda a desconstruir esses estereótipos. Ademais, sempre que cria um personagem, parte de alguém concreto, o que permite manter o distanciamento da visão estereotipada. Assim, por exemplo, quando ela cria uma empregada, está se recriando, recriando sua mãe. Por isso, o seu ponto de vista de escritora, o seu lugar de enunciação, é diferente do canônico.

Nesse sentido, Evaristo se aproxima da escritora moçambicana Paulina Chiziane, que também busca trazer para a literatura histórias colhidas da vida real. A escritora moçambicana é considerada a primeira romancista negra de seu país, mas recusa o rótulo de romancista e se define como contadora de histórias. ${ }^{7}$

De qualquer forma, conforme afirma Nataniel Ngomane ${ }^{8}-$ doutor em Letras pela Universidade de São Paulo e professor na Universidade Eduardo Mondlane, em Maputo, se Chiziane não é a primeira escritora moçambicana, é a voz que mais alto se eleva para resgatar temas "esquecidos" pelos autores africanos que escrevem em português, cujas origens remontam ao colonialismo, ainda que contra o colonialismo eles tenham lutado. Isso porque a escritora trata de questões como o racismo, assimilação, poligamia, subjugação de valores africanos e relações de submissão no lar e entre nações e grupos étnicos. Além disso, a escritora apresenta uma África com o olhar de quem está dentro, procurando retratá-la com suas nuances culturais variadas e não com o reducionismo de quem vem de fora e enxerga o continente como se fosse um só país.

Em entrevista à TV Brasil ${ }^{9}$, Chiziane explica que quando se é africano e se percebe que outras culturas podem ofuscar aquilo que são os valores da sua própria terra, torna-se militante. Esclarece que escreve porque gosta, mas que utiliza esse gosto e esse prazer para preservar "alguma coisa que pode desaparecer", realizando, assim, uma escrita militante. Preocupada em fazer o registro das narrativas orais de comunidades africanas e de suas bases culturais, vai às comunidades recolher histórias. Diz que apesar de haver muitas pessoas empenhadas nesse trabalho, trata-se de um trabalho urgente, pois o mundo está mudando muito rápido, ainda mais com a televisão, que faz com que as novas gerações esqueçam das bases culturais dos seus grupos.

\footnotetext{
7 Segundo Adelto Gonçalves, não seria correto considerar Paulina Chiziane a primeira escritora moçambicana, porque Lília Momplé - ex-secretária geral da Associação dos Escritores Moçambicanos, autora de livros de contos e de uma biografia - apareceu antes de Chiziane, já à época pós-independência. Como Momplé é mestiça e carrega sangue europeu, se o critério for uma "suposta africanidade", Paulina seria a primeira escritora negra moçambicana, mas não a primeira escritora (GONÇALVES, 2012, p. 33).

${ }^{8}$ NGOMANE In Gonçalves. Adelto. Passagens para o Índico: encontros brasileiros com a literatura moçambicana. Org. Chaves, Rita; Macedo, Tânia. Maputo: Marimbique, 2012.
}

${ }^{9}$ Disponível em :https://www.youtube.com/watch?v=ZH4pfDfToSg, acesso em 23.09.2013, às 00:37:42. 
Chiziane revela, ainda, que quando começou a escrever e a colocar mulheres nos seus romances, ouviu muitas críticas, dizendo que isso era feminismo e que não há na literatura lugar para feminismo, que a literatura é lugar para "a grandeza da alma", apesar de ela "não saber o que isso significa". Por isso, no seu país, ninguém "passava cartão" nos seus livros. Começou editando na Alemanha, depois em Portugal e, por fim, em Moçambique.

Em entrevista concedida à pesquisadora Rosália Estelita Gregório Diogo, confirma que privilegia as narrativas orais, reconfigurando a memória social de Moçambique. E quanto à sua recepção no meio literário, diz que foi mal recebida, porque queria romper com tabus, trazer aquilo que é novo. Alguns acharam que ela estava falando sobre feminismo, porque era moda. Outros a consideraram feminista, por escrever para mulheres. Mas a escritora diz que não é assim que se enxerga. Explica que escreve sobre o feminino, sobre as questões que interessam às mulheres e que, por isso, há uma tendência em qualificar pejorativamente seus romances como feministas (CHIZIANE apud DIOGO, 2010, p. 173). Segundo a escritora:

Muitas pessoas consideram que como eu escrevo para as mulheres, eu sou feminista, mas eu não vejo a questão dessa forma. $O$ fato é que sou uma mulher e escrevo sobre temas que me tocam nessa minha condição. $\mathrm{O}$ que me incomoda é que, quando é o homem escrevendo, as pessoas não o chamam de machista e nós, mulheres, quando escrevemos, somos chamadas de feministas. É verdade que eu escrevo muito forte sobre o feminino, sobre as questões que interessam de perto às mulheres. $O$ fato é que a tendência da sociedade é qualificar pejorativamente esses escritos, estigmatizá-los como feministas e eu não gostaria que as coisas acontecessem dessa forma. Não quero ser chamada de feminista. Essa é outra guerra, pois prefiro que os meus livros falem por si e que não seja eu o alvo da mensagem (CHIZIANE apud DIOGO, 2010, p. 173).

Citando Niketche como exemplo, diz que o que pretende é mostrar que há outras maneiras de falar sobre o feminino, diferentes das padronizadas. Por isso, colocou personagens femininas falando de sexo. Enquanto os homens falam de sexo como se tivessem consumido alguma coisa, para as mulheres, o sentimento "é algo que salta".

Sobre as dificuldades editoriais, Chiziane acredita ter enfrentado problemas como escritora que as mulatas não enfrentariam. Segundo ela, o estatuto do mulato em Moçambique é superior. Os portugueses que permaneceram no pós-independência mantiveram seus privilégios, assim como os seus filhos, por conta da mestiçagem. Os filhos de pai branco têm um conceito mais elevado na sociedade.

Conforme explica, em Moçambique não se discute muito a questão do racismo, porque a Constituição diz que não pode haver discriminação racial. No entanto, fato é que não há igualdade racial. A autora conta que no sul, nada se diz sobre o assunto, mas na Zambézia é muito flagrante o estatuto superior do mulato:

Não sei bem o que podemos dizer hoje sobre racismo em Moçambique. O Alegre canto da perdiz é um pouco mais ousado ao abordar o assunto. No fundo, nós fizemos uma luta pela independência. Nesse momento ficou claro que os nossos inimigos eram os portugueses. Mas as questões sobre raça, no sistema colonial, eram muito claras. Fizemos a independência há mais de trinta anos e, desde então, não voltamos a discutir, a fazer o debate sobre revolução. Paramos de fazer o debate sobre unidade nacional e outros temas. E eu, como sempre, não consigo fechar a porta para os debates que não 
são tão populares assim. $\mathrm{O}$ fato é que os portugueses que aqui ficaram no período pósindependência mantiveram os seus privilégios e os seus descendentes também, por conta da sua mestiçagem. São filhos de pai branco e, daí, o conceito, dentro da sociedade moçambicana, é mais elevado. Por exemplo: se tu fores às províncias do norte, como a Zambézia ou Nampula, os empregados dos brancos são mestiços; nos aviões, as funcionárias também são. Raramente, nesses postos de trabalho, se encontram pessoas negras, com a pele escura como a minha ou a sua. Em grandes empreendimentos, hoje, a primeira presença que encontramos é a de mestiços, mas esse assunto não se discute por aqui. A desculpa é que a Constituição diz que não pode haver discriminação pela raça e outras. Só que nos basearmos no que está escrito nela, sem haver que haja um mecanismo de debate público, não basta. Não estamos em igualdade racial de forma alguma. Aqui no sul não se diz nada, mas na Zambézia, que está no centro, e no norte do país, é muito flagrante o estatuto do mulato, que é superior. É o que posso dizer nesse momento sobre a questão do racismo por agora (CHIZIANE apud DIOGO, 2010, p. 180-181).

Em relação ao mercado editorial e a dificuldade na publicação de romances para os afro-brasileiros - no sentido não da cor da pele, mas do tipo de discurso que pretende compartilhar as experiências históricas e cotidianas dos afrodescendentes no Brasil Evaristo também encontrou dificuldades. Segundo Salgueiro, a autora começou publicando desde 1989, na série Cadernos Negros, colaborando também para sua divulgação. Os Cadernos Negros têm sua organização e editoração a cargo do grupo Quilombhoje, que se encarrega do lançamento e distribuição. Trata-se de um processo cooperativo, em que o grupo arca com uma parte e a outra é dividida pelos autores que estiverem participando do volume, a fim de superar as barreiras impostas pelo mercado e atender a uma demanda por um tipo de literatura não oferecida por esse mercado. Os cadernos foram criados em 1978 e, desde então, foram lançados um por ano, alternando poemas e contos de autores afro-brasileiros, dando visibilidade à literatura negra e possibilitando que os descendentes de africanos passassem à condição de sujeitos da escrita (SALGUEIRO, 2004, p. 110 -111 e 121).

Evaristo conta, em entrevista já citada à TV Brasil, que publicava pelo grupo Quilombhoje no momento em que uma das editoras lhe disse que deveria publicar algo individual. Foi então que bancou a publicação do romance Ponciá Vicêncio pela editora Mazza, ficando um ano "no vermelho" por conta disso. E assim, foi bancando os outros livros, como Becos da Memória, Poemas de Recordação e Outros Movimentos e Insubmissas Lágrimas de Mulheres, para o qual contribuiu com sessenta por cento do valor. Disse que somente agora, em 2013, a editora Pallas, do Rio de Janeiro, convidoua para reunir contos de Cadernos Negros e mais um inédito, a fim de publicá-los, sem que a escritora tenha que pagar algo por isso. Conforme explica Evaristo, a maioria dos afro-brasileiros banca a publicação de seus textos. São poucos aqueles que são convidados e que publicam em grandes editoras.

Apesar das demandas contemporâneas pelas trocas culturais e pela multiplicidade discursiva, essa dificuldade que os afrodescendentes ainda enfrentam no mercado editorial se apresenta, provavelmente, como herança da nossa história literária, cujo lugar do discurso era ocupado por homens, brancos, pertencentes à classe dominante. No entanto, esse lugar de enunciação vem sendo, como já visto, 
reorganizado no cenário da literatura, no sentido de permitir as negociações culturais, em favor do compartilhamento das experiências históricas e cotidianas.

Quanto à dificuldade que Paulina Chiziane enfrentou como mulher negra e como escritora em Moçambique, em entrevista concedida à revista moçambicana Maderazinco, por telefone, a escritora diz que:

Ser mulher é muito complicado e ser escritora é uma ousadia. Como é uma ousadia a mulher sair de madrugada ir a praia comprar peixe para vir cozinhar. A mulher está circunscrita num espaço e quando salta essa fronteira sofre represálias, há quem não as sinta de uma forma direta, mas a grande maioria. (...) É sempre uma dificuldade, porque primeiro, eu tenho de provar que sou capaz, depois tenho de conquistar um espaço. Eu tenho que trabalhar muito para mostrar que não foi por acaso que as coisas aconteceram. Mas agora estou numa fase mais estável em que as pessoas já não se assustam e, de certa maneira, já não implicam; mas para chegar até este ponto teve de ser uma batalha. ${ }^{10}$

Na mesma entrevista, Chiziane revela que, para ela, escrever é uma maneira de estar no mundo e que escreve porque precisa do seu espaço. Em primeiro lugar, escreve para existir. Existindo no mundo, sua existência se repete para outras pessoas, através de seus livros. No caso do romance Niketche - seu terceiro romance - publicado em 2002, a escritora diz que o livro tem uma mensagem escondida: "as mulheres, de mãos dadas, podem melhorar o seu mundo". Na história, as mulheres fazem das diferenças um belo mosaico para melhorar as suas vidas. As nortenhas e as sulistas se unem, porque todas precisam umas das outras, apesar dos diferentes hábitos sexuais e do confronto entre a cultura do matriarcado e do patriarcado.

Sobre o fato de chamarem-na de feminista, Chiziane responde, na já citada entrevista a Maderazinco, que apenas se trata de conversa de uma mulher para outras mulheres, porque as mulheres têm um mundo só delas:

Estou-me nas tintas... que o chamem. Eu sou uma mulher e falo de mulheres, então eu sou feminista? É simplesmente conversa de mulher para mulher, não é para reivindicar nada, nem exigir direitos disto ou daquilo, porque as mulheres têm um mundo só delas e é isso que eu escrevi, e espero que isso não traga nenhum tipo de problemas, porque há ainda pessoas que não estão habituadas e não conseguem ver as coisas com isenção. ${ }^{11}$

No entanto, em entrevista à Rosália Diogo, publicada na Revista Scripta, a escritora diz que embora não goste de ser chamada de feminista, trava uma luta a partir da condição do feminino. Nessa perspectiva, no artigo intitulado Eu, mulher...por uma nova visão de mundo, a escritora afirma: "Nós, mulheres, somos oprimidas pela condição humana do nosso sexo, pelo meio social, pelas ideias fatalistas que regem as áreas mais conservadoras da sociedade" (CHIZIANE, 1994, p. 13), o que indica o empenho da escritora na emancipação da mulher. No artigo Eu, mulher... por uma nova visão de mundo, esse empenho da escritora moçambicana fica bem claro, quando afirma:

\footnotetext{
${ }^{10}$ Disponível em http://passagensliterarias.blogspot.com.br/2008/01/entrevista-paulina-chiziane.html. Acesso em 27.09.2013às 14:32:44.

11 Disponível em http://passagensliterarias.blogspot.com.br/2008/01/entrevista-paulina-chiziane.html. Acesso em 27.09.2013às 14:32:44.
} 
Olhei para mim e para outras mulheres. Percorri a trajetória do nosso ser, procurando o erro da nossa existência. Não encontrei nenhum. Reencontrei na escrita o preenchimento do vazio e incompreensão que se erguia à minha volta. A condição social da mulher inspirou-me e tornou-se meu tema. Coloquei no papel as aspirações da mulher no campo afectivo para que o mundo as veja, as conheça e reflita sobre elas (CHIZIANE, 1994, p. 16).

Esse é um dos aspectos que a aproximam de Conceição Evaristo, assim como o fato de terem nascido muito pobres, negras e, principalmente, de terem vontade de transformar as coisas e dar voz aos que não tem, usando, em suas escritas, palavras mais ou menos comuns. Segundo a autora, sobre seus aspectos convergentes com Evaristo:

\begin{abstract}
A questão do racismo que vocês vivem no Brasil é bem diferente da nossa, mas quero dizer que Conceição Evaristo tem algumas coisas em comum comigo, quero dizer da sua luta. De maneira bem ousada, enfrentando situações de opressão. Eu, por aqui, enfrento essas situações de maneira diferente, mas enfrento. Por exemplo, o tabu, os espaços das mulheres, etc. Embora eu não goste que me chamem de feminista, eu faço a minha luta a partir da condição do feminino, da condição de ser negra e mulher. Tem algo que insisto em dizer depois de tanto trabalho - o fato de ser mulher e negra assume um estatuto diferenciado nessa sociedade. Se eu fosse homem, e branco, meu estatuto seria muito alto. Os problemas que eu enfrentei para me afirmar como escritora, as mulheres mulatas não enfrentaram, os homens brancos muito menos. Daí, eu venho de um histórico de muita luta. O pouco que eu tenho, em termos de reconhecimento, embora seja resultado de muito trabalho, é pouco. Sou mais reconhecida fora do meu país do que aqui dentro. Penso que o que mais me unifica com a Conceição Evaristo é isso: ela também vem de uma condição social muito pobre, ela é negra e tem que enfrentar várias barreiras. Portanto, o que vejo muito forte entre mim e nela é a vontade de transformar as coisas, de ver um mundo novo. Talvez seja por isso que eu me vejo tão próxima dela e das suas escritas. As palavras que usamos são palavras mais ou menos comuns. Penso que seja esse um forte aspecto. Eu vou trabalhando, lutando, tentando dar voz aos que não a têm, assim como faz Conceição Evaristo. Tento desenterrar alguns pontos obscuros, aquelas realidades obscurecidas pela sociedade (CHIZIANE apud DIOGO, 2010, p.181-182).
\end{abstract}

Para Evaristo, conforme entrevista ao Imagem da Palavra, a literatura é uma forma de libertação e de denúncia. Comparando sua literatura com a dança de Michael Jackson, acrescenta que escrever é, para ela, um momento de plenitude, como toda forma de arte. ${ }^{12}$

A autora, no já referido V Colóquio das Mulheres em Letras, fala sobre o livro Becos da Memória ${ }^{13}$ e conta um pouco da sua vida. Esse romance não é objeto central dessa pesquisa, mas, por ser confundido com a autobiografia da escritora, será mencionado em alguns pontos desse capítulo. Evaristo revela que algumas das personagens do romance foram criadas a partir das histórias reais de sua família e da experiência que teve ao nascer e morar até os vinte e quatro anos em uma favela de Belo

12 Disponível no blog http://nossaescrevivencia.blogspot.com.br/search/label/videos, acesso em 19.09.2013, às 20:40:37.

${ }^{13} \mathrm{O}$ romance Becos da memória é o segundo romance de Conceição Evaristo, publicado em 2006, mas o primeiro escrito por ela, no final dos anos 70 e início dos anos 80. 
Horizonte. No entanto, faz a ressalva de que o texto foi surgindo com memórias perdidas, inventadas e criadas. Segundo ela:

Nada ali é verdade. Nada do que está descrito ali aconteceu do jeito que está narrado. Mas muito do que está em Becos foi inventado a partir do acontecido. Eu diria que Becos da memória é uma escrita que está na confluência entre a memória e a ficção. Seria uma espécie de ficções da memória. A memória ficcionaliza, pois a memória esquece e muitas vezes não quer lembrar. Talvez contando como o livro nasceu seja possível uma apreensão melhor do gênero em que ele se encaixa - memória, ficção ou autobiografia - ou entender como a escrita de Becos navega nas águas da memória e muito nas águas da invenção. Eis a gênese de Becos da Memória. ${ }^{14}$

De acordo com Evaristo, o romance "é uma espécie de ficção da memória, porque alguns eventos reais rememorados serviram de criação para o texto."15 Assim, por exemplo, a autora explica que a favela descrita no livro é uma invenção geográfica de um espaço que realmente existiu, em que ela morou até os vinte e quatro anos, e tinha como vizinhança bairros ricos e nobres, como o Bairro da Serra, Cruzeiro e Sion.

Cumpre ressaltar a analogia que a personagem Maria Nova faz entre a casa grande e a senzala e entre os bairros nobres e a favela por eles circundados. Essa personagem é muito confundida com Evaristo. A autora esclarece, no referido Colóquio, que Maria Nova é "uma parente muito próxima a ela", mas que com ela não se confunde, já que há entre elas invenção. Também afirma que Ponciá Vicêncio, personagem do romance homônimo, corpus dessa pesquisa, pode ser ainda menos confundida com a escritora.

Evaristo conta, ainda, no referido colóquio, que sua família é extremamente católica, que sua tia era rezadeira e como ela era uma das poucas meninas que sabia ler, cabia a ela a leitura das ladainhas em latim. Nesse ponto, sua história se confunde com a de Maria Nova, personagem de Becos da Memória, que também era quem sabia ler na favela e a quem cabia a leitura das ladainhas.

Também a escritora Paulina Chiziane teve uma educação religiosa ocidentalizada, em ambiente cristão. Diferentemente de Evaristo, sua família não era católica. Conforme afirma em entrevista concedida à pesquisadora Rosália Diogo, seus pais eram presbiterianos. Entretanto, Chiziane, criada em Maputo, foi estudar na escola católica, onde recebeu a "formação de uma identidade feminina bem rígida, patriarcal", o que manteve a escritora bem longe da realidade de uma cultura matriarcal. Conta que na província de Gaza, no sul de Moçambique, onde nasceu, há "um machismo terrível" e que quando chegou na Zambézia, norte do país, deparou-se com uma sociedade matriarcal, em que os comportamentos femininos e masculinos eram totalmente diversos dos que observava no sul (CHIZIANE apud DIOGO, 2010, p. 173). Segundo Chiziane:

Quando chego na Zambézia, que é uma província no Norte do país, a trabalho, encontro uma sociedade matriarcal em que os comportamentos masculino e

14 Disponível no blog http://nossaescrevivencia.blogspot.com.br/search/label/videos, acesso em 19.09.2013, às 20:45:48.

15 Idem. 
feminino são completamente diferentes do que eu vivia e observava no Sul. Primeiro foi um choque, depois me diverti com isso. E daí escrevi o livro, inspirada nas mulheres da Zambézia e pensando "aquelas mulheres são loucas". Ainda agora parece que estou a ver aquelas mulheres sentadas em volta de uma mesa, comendo, bebendo cerveja e conversando naturalmente, sem perceber que eu estava fazendo a minha pesquisa. E eu ouvi coisas que nunca imaginei ouvir na vida (CHIZIANE apud DIOGO, 2010, p. 174).

Nesse ponto, a personagem Rami, do romance Niketche, assemelha-se à autora, uma vez que, nascida e criada no sul de Moçambique, recebeu uma educação cristã. Casou-se sem conhecer os ritos de iniciação, contra os quais a igreja gritou heresias. A personagem também se surpreende ao entrar em contato com a cultura do norte, através de uma professora "de amor" nortenha. Eis o desabafo de Rami:

Estas aulas são os meus ritos de iniciação. A Igreja e os sistemas gritaram heresias contra essas práticas. Analiso a minha vida. Fui atirada ao casamento sem preparação nenhuma. Revolto-me. Andei a aprender coisas que não servem pra nada. Até a escola de Ballet eu fiz - imaginem! Aprendi todas aquelas coisas das damas europeias, como cozinhar bolinhos de anjos, bordar, boas maneiras, tudo coisas de sala. Do quarto, nada! A famosa educação sexual resumia-se ao aparelho reprodutor, ciclo disto e daquilo. Sobre a vida a dois, nada! Os livros escritos por padres invocam Deus em todas as posições. Sobre a posição a dois, nada! E na rua havia as revistas de pornografia. Entre a pornografia e a santidade, não havia nada! Nunca ninguém me explicou por que é que um homem troca uma mulher por outra. Nunca ninguém me disse a origem da poligamia $^{16}$. Por que é que a Igreja proibiu estas práticas tão vitais para a harmonia de um lar? Por que é que os políticos da geração da liberdade levantaram o punho e disseram abaixo os ritos de iniciação? É algum crime ter uma escola de amor? Diziam eles que essas escolas tinham hábitos retrógrados. E têm. Dizem que são conservadoras. E são. A igreja também é. Também o são as universidades e todas as escolas formais. Em lugar de destruir as escolas de amor, por que não reformá-las? O colonizado é cego. Destrói o seu, assimila o alheio, sem enxergar o próprio umbigo. E agora? Na nossa terra há muito desgosto e muita dor, as mulheres perdem os seus maridos por não conhecerem os truques de amor. (...) Aprendi que os ritos de iniciação são uma instituição mais importante que todas as outras instituições formais e informais juntas, cujos segredos não se divulgam nunca (CHIZIANE, 2012, p. 44-45).

Enquanto a escritora Chiziane e a personagem principal de seu livro mais conhecido no Brasil - Niketche - foram criadas no seio de uma sociedade machista e patriarcal, a infância da escritora Conceição Evaristo, como já analisado

16 Na citada entrevista concedida à Rosália Diogo, Chiziane explica que a região sul, antes da colonização, era patriarcal e a favor da poligamia. Com o cristianismo, foi instalada oficialmente a monogamia. Já no norte, que era matriarcal, e onde não havia espaço para a poligamia, instalaram-se os muçulmanos e implementaram a poligamia. Por isso, há uma grande confusão. Chiziane, pessoalmente, não é a favor da poligamia, mas entende que a poligamia é uma realidade sobre a qual é preciso legislar, pois os homens não a deixam de praticar informalmente. Assim, sendo a poligamia reconhecida, seria possível dar proteção aos filhos das outras mulheres, para que possam ter uma "identidade" e serem reconhecidos como filhos legítimos de uma família. Também seria possível dar proteção às mulheres que vivem no sistema tradicional poligâmico, que são a maioria, já que as cidades são pequenas e a zona rural imensa. No sistema poligâmico, o homem quando resolve ter a segunda mulher, deve resolver a situação com a primeira, dividindo seus bens, deixando a parte dela resolvida para construir a nova vida, sem deixá-la desprotegida. Nesse sentido, a escritora se declara apologista de uma legislação que regule a poligamia. 
contrastivamente, foi marcada pelo referencial feminino. Evaristo revela, em entrevista realizada no programa "Tarde de Ossobô"17, na TVS de São Tomé e Príncipe, que as mulheres são muito importantes na sua vida, porque ela vem de uma família dirigida por mulheres. Diz que aprendeu muito mais sobre a história das mulheres da sua família, do que sobre história dos homens.

Nesse aspecto, a autora se confunde com a personagem Ponciá Vicêncio, de seu romance homônimo. A personagem é criada no matriarcado da Vila Vicêncio, onde as mulheres ficam responsáveis pela educação dos filhos e tomam a maior parte das decisões sobre as questões domésticas, enquanto os homens vão para a terra dos brancos trabalhar. A profissão de lavadeira de Maria Vicêncio, mãe de Ponciá, é a mesma da mãe de Evaristo.

Essa convergência também pode ser observada no romance Becos da Memória, espécie de "ficção da memória" da escritora, como Evaristo definiu, em que a personagem Maria Nova, que pode ser entendida como sua "parente próxima" vem de uma família de matriarcas lavadeiras.

No mesmo sentido, o artigo do pesquisador Luiz Henrique Oliveira sustenta que a personagem Maria Nova compõe-se de "rastros do sujeito autoral: menina, negra, habitante durante a infância de uma favela e que vê na escrita uma forma de expressão e resistência à sorte do seu existir". Isso inclui o fato de serem oriundas de famílias de matriarcas lavadeiras, transitando entre o mundo da riqueza e o da miséria, fazendo a mediação cultural que contribui para o processo de building de ambas (OLIVEIRA, 2009, p. 622).

Tal convergência entre a vida de Conceição Evaristo e das personagens Maria Nova e Ponciá Vicêncio, ambas provenientes de famílias dirigidas por matriarcas lavadeiras, pode ser verificada também na introdução do livro Poemas de Recordação e Outros Movimentos, em que Evaristo se refere de uma forma extremamente poética às suas lembranças de menina das roupas estendidas no varal. Eis um trecho lido pela escritora na Primeira Conferência das Escritoras Brasileiras em Nova Iorque:

O olho do sol batia sobre as roupas estendidas no varal e mamãe sorria feliz. Gotículas de água aspergindo a minha vida menina balançavam ao vento. Pequenas lágrimas dos lençóis. Pedrinhas azuis, pedaços de anil, fiapos de nuvens solitárias caídas do céu eram encontradas ao redor das tinas e das bacias de lavagens das roupas. Tudo me causava uma comoção maior. A poesia me visitava e eu nem sabia. ${ }^{18}$

Ponciá Vicêncio, apesar de inserida em uma comunidade matriarcal, que através das mulheres, passava sua herança cultural ancestral para seus descendentes, aprendeu a ler e a escrever com os missionários católicos. Quando morava na roça, gostava de ler e guardava diversas revistas e jornais velhos para ficar lendo e relendo. Ela achava que a leitura "lhe abriria meio mundo ou até o mundo inteiro" (EVARISTO, 2003, pp. 90 91). Todavia, ao se deparar com a sua impotência de transformar sua vida na cidade

17 Disponível no blog: http://nossaescrevivencia.blogspot.com.br/search/label/videos, acesso em 20.09.2013, às 00:44:52.

${ }^{18}$ Disponível em: https://www.youtube.com/watch?v=aZGGz8kw51c, acesso em 22.09.2013, às 19:34:17. 
grande, a personagem juntou as revistas e jornais, queimando tudo, certa de que de nada adiantava ter aprendido a ler, que de nada adiantava essa cultura ocidentalizada para ela. Passou a "gastar a vida em recordar a vida, que era também uma forma de viver" (ibid., p. 91)

Essa passagem indica o caminho da memória como possibilidade para manter vivas as tradições ancestrais. É o que Evaristo explica em já citada entrevista ao programa 3 a 1 da TV Brasil, ao mencionar a diferença entre os imigrantes que vieram para o Brasil e os povos africanos da diáspora. A escritora esclarece que, normalmente, os imigrantes trazem algum objeto consigo, facilitando a rememoração do passado, como um retrato, por exemplo. Já os povos africanos escravizados trazem consigo somente sua memória. Nesse sentido, sua ancestralidade já vem "diluída".

Por isso, se a cultura ocidental não abre as portas do mundo para Ponciá, o ato de recordar a vida é uma outra forma de vivê-la, revigorando essa ancestralidade diluída e a sua memória. Esse ato de retorno "às origens" se concretiza quando a personagem volta para a vila em que foi criada, reencontrando a sua força na união com a sua comunidade, para ressurgir no barro, através das suas esculturas, da sua arte.

Assim como Evaristo e a personagem Ponciá Vicêncio, Paulina Chiziane utiliza a arte como forma de revigoração da memória da cultura africana, não permitindo que seja ofuscada pela do colonizador. A escritora considera um trabalho urgente o registro da oralidade, através da recolha de histórias em comunidades. ${ }^{19}$

Sobre a importância de não esquecer a ancestralidade africana, cabe retomar a entrevista concedida por Evaristo ao programa da televisão santomense "Tarde de Ossobô", em que, ao ser questionada sobre o porquê da denominação "escritora afrobrasileira" em vez de apenas "escritora brasileira", responde que se trata de um exercício político de uma identidade que não quer esquecer a sua ancestralidade. Diz que essa identidade hifenizada demonstra que está marcada por raízes africanas. Além disso, ressalta que se afirmar como escritora afro-brasileira é sair do lugar de mulher negra que permeia o imaginário brasileiro, ligado a cozinhar e a cuidar da casa. Sair desse lugar é mostrar que a mulher negra também é capaz de produzir conhecimento ${ }^{20}$.

Em entrevista ao mesmo programa, Evaristo afirma que o fato de grupos terem que "afirmar sua identidade", indica "uma falha no processo histórico de relação" com outros grupos, já que em um determinado momento, foram subjugados, tanto na África, quanto no Brasil. Para ela, a utopia seria que os povos conseguissem chegar a um momento de tradução em que as diferenças pudessem ser assimiladas com boa vontade. Acredita que, no Brasil, há ainda um longo caminho a ser percorrido e esclarece que, enquanto a África do Sul e os EUA se apresentam como países racistas, o Brasil é um "país cínico", dando como exemplo a reiteração, nos discursos hegemônicos, de uma democracia racial que nunca existiu. ${ }^{21}$

${ }^{19}$ Entrevista à TV Brasil. Disponível em :https://www.youtube.com/watch?v=ZH4pfDfToSg, acesso em 23.09.2013, às 00:37:42.

20 Programa "Tarde de Ossobô", da televisão santomense TVS: http://nossaescrevivencia.blogspot.com.br/search/label/videos. Acesso em 01.10.2013, às 10:48:42.

${ }^{21}$ Entrevista para TV Brasil, Evaristo: https://www.youtube.com/watch? $=$ UKyB7b-zX4s, acesso em 22.09.2013, às 21:19:34. 
A despeito de qualquer ideia de essencialismo ou de purismo racial ou cultural, diz que a afirmação étnica do negro brasileiro passa a ser bem colocada quando é colocada por um negro, "falada de dentro". Acrescenta que é indiscutível que Jorge Amado tenha sido o primeiro escritor a colocar o negro na posição de "o mesmo", de sujeito em relação ao branco na literatura. Entretanto, seria possível fazer um paralelo entre Jorge Amado na literatura e Gilberto Freyre na sociologia, já que ambos têm uma "boa vontade", mas "glamorizam" a miscigenação por meio de uma escrita de "sedução". Conforme esclarece, Freyre e Jorge Amado foram um avanço na época, mas instituíram uma imagem de cordialidade entre o negro e branco que não existe. A escritora esclarece, ainda, que, no Brasil, quando se fala sobre miscigenação que tende a embranquecer, há uma boa aceitação. Todavia, se for o contrário, vira "um dado complicador." A mestiçagem é bem aceita "enquanto o negro dilui-se no branco." 22

Assim, reconhecer uma identidade marcada por raízes africanas como postura política é instrumento de união e resistência para os afrodescendentes, na luta pela igualdade material de direitos. Como propõe Evaristo, é através do reencontro com a sua comunidade e da rememoração da sua cultura e identidade, que Ponciá Vicêncio se fortalece. Outro aspecto convergente entre a escritora e a personagem, é a arte - o barro para Ponciá e a escrita para Evaristo - instrumento de transcendência e de continuidade dessa cultura. Da mesma maneira, a escritora Paulina Chiziane utiliza a literatura como forma de luta.

Como a personagem Ponciá Vicêncio de Conceição Evaristo - aqui comparamos a personagem Ponciá com a escritora Chiziane - a escritora Paulina Chiziane aprendeu a ler e a escrever o português com as missões católicas. Ao contrário de Ponciá, a escrita em língua portuguesa virou sua arma de luta. Todavia, segundo artigo de Teresa Noronha, publicado no blog da Carmo Editora $^{23}$, o emprego da língua portuguesa para Chiziane não foi isento de conflitos relacionados à sua identidade, já que a primeira língua que aprendeu foi o chope e porque a língua portuguesa estava ligada àqueles que tinham levado sua família para o trabalho forçado, na sua infância. Além disso, conforme o citado artigo, a escritora foi criada numa atmosfera antibranca muito acentuada, pois o contato entre brancos e negros na sociedade colonial era, segundo ela, quase inexistente. Por causa da escolarização, foi preciso se adaptar ao português. Para Chiziane, talvez a forma de não trair "os seus" seja reivindicar nessa língua alheia, um lugar para o seu universo de infância.

Chiziane conta na referida entrevista, que os seus estudos aconteciam embaixo das árvores, em aulas ao ar livre, já que as escolas eram muito pobres e, por não haver cadernos para todos, o alfabeto era escrito no chão. Quando chovia ou ventava, as aulas tinham que ser suspensas.

Revela, ainda, que sua escrita séria começou em plena guerra civil, embaixo dos estrondos de explosão de bombas. No início, escrevia contos para jornais e revistas do país, até que, em 1990, publicou o primeiro romance: Balada de Amor ao Vento. A

\footnotetext{
${ }^{22}$ Idem.

23 Disponível em: http://carmoeditora.blogspot.com.br/p/paulina-chiziane-entre-tradicao-e.html. Acesso em 27.09.2013, às 02:13:04.
} 
escritora relata que durante a guerra civil, mesmo embaixo dos estrondos, sentia necessidade de continuar escrevendo, de terminar o texto. Para ela, escrever é uma questão de paixão e a inspiração é algo que não sabe de onde vem, mas sabe que vem "do fundo".

Chiziane militou ativamente pela independência de Moçambique, participando da FRELIMO (Frente de Libertação de Moçambique), no ano de 1974, quando tinha apenas dezenove anos. Conta que o movimento se dividia em dois: a parte armada oficial e os clandestinos. Como ela era muito jovem, fazia coisas sem saber quem mandava. Distribuía cartazes e panfletos sobre a necessidade de independência. Entretanto, a escritora revela que esse período foi a sua grande escola de vida, o que a ajudou a se tornar uma pessoa mais determinada "para sonhar e realizar". Antes de participar do movimento, seus escritos eram "corações e flores", mas depois que viu gente correndo e morrendo, passou a ver o amor de forma diferente.

Assim, sua primeira escrita séria ocorreu, justamente, quando trabalhou na Cruz Vermelha, durante a guerra civil que seguiu a independência, reflexo da guerra fria e, principalmente, de disputas pelo poder político no novo estado nacional. Nesse período, estava decepcionada com a política, questionando a razão da guerra pela independência de Moçambique, já que a guerra civil continuava no país. Não compreendia qual o sentido da política se as pessoas não tinham direito à vida. Foi nesse momento que escreveu o seu segundo romance, Ventos do Apocalipse, porque era notório que o apocalipse estava todos os dias na vida dos moçambicanos.

A luta da escritora continuou através da literatura. Isso fica mais evidente em palestra proferida por Chiziane na Universidade Eduardo Mondlane, com o tema "A mulher e a literatura em Moçambique", 24 em que afirma o poder da palavra no processo de construção e de destruição. Para a escritora, com a palavra é possível construir tudo, assim como é possível destruir tudo, dependendo da forma como a palavra é usada. Chiziane questiona, também, o fato de a literatura masculina ser mais valorizada, já que a mulher foi a grande impulsionadora da literatura oral: "a tradição da literatura provou que ela é uma ação puramente feminina". ${ }^{25}$ Critica a conotação que as obras escritas por mulheres têm tido na sociedade, uma vez que vários livros escritos por mulheres, ainda que versem sobre diversos aspectos da sociedade, são relacionados com o feminismo, simplesmente por terem sido escritos por indivíduos do sexo feminino: "Das leituras que fiz, em obras de mulheres moçambicanas, como a Noémia de Sousa, Clotilde Silva, Lília Momplé, Lina Magaia e mesmo nas minhas próprias obras não encontrei o feminismo, ainda que nelas a mulher seja descrita. Ela aparece sim a desempenhar um determinado papel na sociedade e os romances não são necessariamente feministas ou que surgem para defender o movimento". ${ }^{26}$

\footnotetext{
${ }^{24}$ Palestra proferida em razão do segundo encontro Hispano-Africano de Escritores, organizado pela Embaixada da Espanha em Moçambique, em cooperação com a Universidade Eduardo Mondlane. Disponível em: http://carmoeditora.blogspot.com.br/p/paulina-chiziane-em-noticias-2.html Acesso em 27. 09. 2013, às 01:28:35.

${ }^{25}$ Jornal da Carmo Editora. Disponível em: http://carmoeditora.blogspot.com.br/p/paulina-chiziane-emnoticias-2.html Acesso em 27. 09. 2013, às 01:28:35.

${ }^{26}$ Idem.
} 
Além disso, Chiziane chama atenção para a necessidade de "democratização" da literatura entre as mulheres, uma vez que, em sua opinião, muitas mulheres escritoras reproduzem o modelo machista quando descrevem a mulher:

\begin{abstract}
Algumas vezes confundimos a literatura feminina com a literatura escrita por mulheres e penso que isso é um erro, porque a maior parte das mulheres ainda escreve com uma ideia machista. (...) Nós, quando vamos descrever, o único modelo que conhecemos é o modelo machista e se não nos apercebemos, fazemos a reprodução desse modelo. Muitas vezes surpreendo-me ao ver mulheres a usarem a linguagem dos homens (...) Para mim, uma mulher é um mundo de pensamentos, de sentimentos, de sonhos, de realizações, de frustrações... Se eu tenho uma personagem mulher, significa descrever todo esse universo, mas muitas escritoras, quando vão descrever outras mulheres, imitam os homens. ${ }^{27}$
\end{abstract}

Essa preocupação quanto à reprodução do modelo machista e a consequente necessidade de "deslocamentos" na literatura do seu lugar canônico também é levantada por Evaristo quanto à literatura brasileira. Em entrevista ao programa Imagem da Palavra, Evaristo fala sobre os estereótipos ligados ao negro na literatura brasileira, aparecendo como infantis, preguiçosos e incapazes e sobre os estereótipos ligados à mulher negra, retratada como "boa de cama" e sendo dificilmente ficcionada como mãe, como as personagens Rita Baiana, Bertoleza e Gabriela. Questiona se a literatura não estaria, no nível do recalcado, negando uma matriz africana para a sociedade brasileira, já que não pensa a mulher negra no centro da sua prole, na sua ambiência cultural. Quando ela é representada, traz a figura de mãe preta de Casa Grande e Senzala.

Por outro lado, Evaristo chama atenção para o fato de as mulheres negras exercerem um contra-poder dentro da casa do senhor, criando os filhos das amas junto com os filhos que tinham com homens negros e também com os filhos que tinham com o senhor. Elas contribuíram, assim, segundo Evaristo, no citado programa, para modificar a língua portuguesa, a forma de se falar o português.

Voltando à Chiziane, cumpre ainda ressaltar a sua identificação com o romance Ponciá Vicêncio, de Conceição Evaristo, em que a escritora moçambicana diz, em entrevista já citada à Rosália Diogo, que quando fecha os olhos e se imagina no Brasil, pensa que poderia ter sido ela a escrever o romance, como se seu espírito estivesse naquela história:

O que tenho a dizer é que eu não tenho palavras para explicar o que vou dizer: peguei o livro Ponciá Vicêncio para ler e começo a identificar-me com ele. Li também poemas da recordação e outros movimentos e agradei-me muito. A sonoridade me chamou atenção também. Conceição escreve, na obra, assuntos completamente diferentes dos meus, mas quando fecho os olhos, me vejo no Brasil e penso que poderia ter sido eu a escrever o romance. A obra me fez sentir muito próximo dela. É como se meu espírito estivesse naquela história. Recebi essa obra diretamente das mãos dela e, fisicamente, não pareço com ela, mas tem algo. Quando se olha para ela e para mim, fica a sensação de pessoas que viveram no mesmo lugar, ou são irmãs. Eu realmente não tenho palavras para explicar. Quando ela esteve cá estivemos juntas por alguns lugares de Maputo e eu

27 Jornal da Carmo Editora. Disponível em http://carmoeditora.blogspot.com.br/p/artigo-3.html. Acesso em 27.09.2013, às 02:01:44. 
gostaria de tê-la levado em muito mais lugares dos que pude levar porque o programa dela estava muito apertado. Mas a Conceição Evaristo passa por uma pessoa moçambicana, e se eu disser que ela é minha irmã mais velha ou mais nova, com certeza as pessoas acreditarão (CHIZIANE apud DIOGO, 2010, p.179 -180).

Analisando a vida de Chiziane, é possível identificar aspectos convergentes com a trajetória da personagem Ponciá Vicêncio, como a educação através de missionários católicos, a infância na roça e o pouco contato com pessoas brancas. A personagem é criada na Vila Vicêncio - uma comunidade dos negros ex-escravos do Coronel Vicêncio - e somente viaja para a cidade aos dezenove anos. Ela aprende a ler e a escrever na própria Vila, através dos missionários católicos.

A escritora Chiziane, assim como a personagem Ponciá, segundo Adelto Gonçalves, foi criada no campo, tendo lá vivido até os sete anos de idade, quando se mudou para os subúrbios de Maputo. No campo, Chiziane falava a língua materna, o chope. Sua mãe também era camponesa, como a mãe de Ponciá, e ficava por vezes uma semana toda sem voltar pra casa, a cuidar das plantações de mandioca. Já o seu pai, diferentemente do pai de Ponciá, que trabalhava na roça, era alfaiate de esquina (GONÇALVES, 2012, p.34).

$\mathrm{Na}$ cidade, ainda de acordo com Gonçalves, Chiziane teve que aprender o português na escola, enquanto era obrigada a utilizar o ronga, língua nativa de Maputo, para se comunicar na cidade (Ibid., p.34). Mais tarde, frequentou os estudos superiores de Linguística na Universidade Eduardo Mondlane, sem concluí-los (Ibid., p. 34).

Cabe destacar um ponto de divergência fundamental entre ambas. Enquanto a escritora Paulina Chiziane nasce em uma sociedade patriarcal, a personagem Ponciá Vicêncio é criada numa sociedade matriarcal, aproximando-se mais, nesse aspecto, da escritora Conceição Evaristo.

Sobre a situação da mulher negra atualmente, Evaristo afirma, em entrevista já citada à TV Brasil, que algumas estão hoje em outro patamar. Por isso, "não dá pra fazer da vida passada um muro de lamentações". Acredita que um grande avanço é termos hoje uma mulher como presidenta. No entanto, grande parte das mulheres negras continua subalternizada, estuda por menos tempo e ganha salários menores. A grande maioria ainda está na "base da pirâmide social brasileira", pois desde a escravidão, as mulheres negras estiveram "na linha de frente de trabalho" e da pobreza. ${ }^{28}$

Em relação à situação da mulher em Moçambique, Chiziane apresenta uma visão positiva, conforme entrevista à Rosália Diogo, relatando que houve uma viragem considerável em trinta anos no que se refere às aspirações das mulheres. Conta que no período em que ocorreu a independência, as mulheres ficavam sentadas, fazendo tricô e esperando o príncipe encantado. Hoje, sonham em estudar, sonham com algo além de serem mães:

Quando se deu a independência eu tinha 18 anos. Significa que eu vivi o período colonial, um pouco da visão das mulheres moçambicanas daquela época. Eu fui do

${ }^{28}$ Entrevista para TV Brasil, Evaristo: https://www.youtube.com/watch?v=UKyB7b-zX4s, acesso em 22.09.2013, às 21:19:34. 
tempo, e tenho prazer de informar, das mulheres que faziam bordados, ficavam sentadas na varanda, em que as mulheres faziam o enxoval, esperando um príncipe, faziam croché, tricot. Portanto, era essa a realidade do período em que se deu a independência. $\mathrm{Eu}$ tenho hoje uma filha moça e observo em volta que toda mulher deseja ser alguma coisa na vida, ainda que casando-se e tendo filhos, mas sonha em ser professora, campeã olímpíca, empresária. Portanto, houve uma viragem considerável em 30 anos. Mas o mais importante dessas transformações é que toda mulher luta por uma vida nova, tem esperança. As mulheres são inquietas nesse sentido, mesmo com todos os problemas que enfrentamos. Esse, para mim, foi o maior ganho trazido pela independência, por grupos como a Organização das Mulheres Moçambicanas - OMM e o Fórum Mulher. E tantos outros. Mas reafirmo que o novo horizonte me deixa esperançosa. Eu viajo muito pelo campo e vejo que todo sonho de uma mulher mãe, por mais pobre que ela seja, é ver a sua filha na escola, em busca de desenvolvimento. Prefiro mais falar do que se ganhou, embora tenhamos tantos problemas como violência, aids e outros (CHIZIANE apud DIOGO, 2010, 176).

Assim, apesar de a grande maioria das mulheres negras ainda ocuparem, no Brasil, a base da pirâmide social e, em Moçambique, sofrerem desvantagens em relação às brancas e mulatas no mercado de trabalho, as duas escritoras se mostram otimistas em relação à situação atual da mulher e suas perspectivas futuras nos dois países.

Tratando mais a fundo a questão do racismo em Ponciá Vicêncio do que Chiziane em Niketche, a afirmação de Conceição Evaristo de que algumas mulheres negras já "estão em outro patamar", ao contrário de esvaziar a necessidade da luta pela resistência, motiva-a ainda mais, uma vez que reflete a realização de algumas conquistas, embora muito haja ainda pela frente.

Sobre a mulher em Moçambique, Chiziane também se mostra esperançosa, pois, apesar dos problemas que ainda são enfrentados, como aids e violência, as mulheres lutam por uma vida nova, por uma vida profissional e se sentem motivadas. Segundo ela: "afasto pouco a pouco os obstáculos que me cercam e construo um novo caminho na esperança de que, num futuro não muito distante, as mulheres conquistarão maior compreensão e liberdade" (CHIZIANE, 1994, p.17).

Assim, as visões e as trajetórias das duas escritoras e das suas personagens, permeadas por questões femininas e raciais, apesar dos muitos pontos divergentes apontados, cruzam-se em diversos aspectos.

As incursões realizadas nos dois romances e nos discursos das duas autoras, por meio de entrevistas, palestras e colóquios dos quais participaram, demonstraram o compromisso de ambas com a denúncia dessas situações de interseção de exclusão racial e de gênero. Apesar de as discussões raciais estarem mais fortemente presentes no romance Ponciá Vicêncio, permeando-o do começo ao fim, a questão também é pincelada em Niketche. Já a problemática de gênero, ao contrário, permeia todo o romance Niketche e pontualmente o romance Ponciá Vicêncio.

Também em relação às entrevistas analisadas das duas autoras, foi possível observar que a questão de gênero é crucial para Paulina Chiziane, enquanto que a racial parece ser circundante no seu discurso. Já no discurso de Conceição Evaristo, as duas questões aparecem mais estreitamente ligadas.

Talvez essa ênfase maior na questão de gênero pela escritora moçambicana se 
deva, de um lado, ao fato dos costumes tradicionais da sociedade moçambicana do sul insistirem menos escrupulosamente do que a brasileira em manter um distanciamento entre os lugares que pertencem à mulher e ao homem, prolongando as formas estruturais de dominação do homem sobre a mulher. É o que demonstra claramente o romance Niketche e as pesquisas ${ }^{29}$ realizadas no pós independência em bairros da periferia de Maputo - onde nasceu Chiziane - em que rígidos padrões de autoridade são conservados nas práticas religiosas, nas estratégias de casamento e no controle da sexualidade.

Essas práticas tradicionais teriam se perpetuado na clandestinidade, para contornarem o desencorajamento no campo político. A força de continuidade das práticas tradicionais estaria, segundo Loforte, no fato de que cumprem funções sociais, funcionando como um dispositivo de certa utilidade para manutenção da autoridade, já que justificam o estado atual de determinada cultura, invocando sua "referência, sua herança e testemunho" (LOFORTE, 2003, p.4).

De outro lado, apesar de o histórico de discriminação racial existir desde o colonialismo, $99 \%$ da população de Moçambique é de negros, ${ }^{30}$ o que nos faz arriscar dizer que talvez a questão racial seja menos dramática em Moçambique do que no Brasil, uma vez que em Moçambique os negros são maioria. Já no Brasil, a população que se autodeclara negra é minoria. Segundo o Censo de 2010, a população que se autodeclara parda é de $43,1 \%$, enquanto a branca é de $47,7 \%$ e a negra de $7,6 \%{ }^{31}$, o que coloca a população negra, se não se incluir os pardos, como pequena minoria.

Apesar de não ser questão central em Niketche e de não ter aparecido tão fortemente como a questão de gênero nas entrevistas analisadas da autora moçambicana, a questão racial é abordada com muita ênfase em $O$ alegre canto da perdiz, romance publicado em 2008, em Lisboa, em que a autora fala sobre o estatuto superior do branco e dos negros assimilados aos valores do colonialismo.

Além disso, como disse a própria Chiziane, em entrevista à Rosália Diogo, seu histórico é de muita luta, assim como o de Conceição Evaristo, pois o fato de ser mulher e negra faz com que assuma um estatuto diferenciado na sociedade. Diz que se fosse homem e branco, seu estatuto seria muito alto, porque os problemas que enfrentou para se afirmar como escritora, as mulheres mulatas não enfrentariam e os homens brancos muito menos. Em termos de reconhecimento, o que tem é pouco, apesar de ser resultado de muito trabalho, pois é mais reconhecida fora do seu país do que dentro dele (CHIZIANE apud DIOGO, 2010, p. 181-182).

No já citado artigo "Eu, mulher... Por uma nova visão do mundo" a escritora afirma que a sua maior realização "virá no dia em que conseguir lançar na terra fértil a semente da coragem e da vontade de vencer nos corações das mulheres que pertencem à geração do sofrimento" (CHIZIANE, 1994, p. 13).

\footnotetext{
${ }^{29}$ Pesquisas realizadas nos bairros de Malhazine (1984 e 1985), Laulane e Mahotas (1992 e 1993) In LOFORTE, Ana Maria. Mulher, poder e tradição. In: Outras Vozes, n 5, Novembro de 2003. Disponível em http://www.wlsa.org.mz/?_target_=Tex_MulherPoderTrad. Acesso em 24.10.2013, às 22:43.

30 Fonte: Recenseamento Geral da População e Habitação, 1997, Instituto Nacional de Estatística. THOMAZ e CACICA-BAVA, 2001, p.33, apud COSTA, Op. Cit., p. 102).

${ }^{31}$ Disponível em : http://www.brasil.gov.br/educacao/2012/07/censo-2010-mostra-as-diferencas-entrecaracteristicas-gerais-da-populacao-brasileira. Acesso em 24.10.2013, às 23:49. 
Assim, ainda que Chiziane pareça enfatizar mais a questão de gênero do que Evaristo, os romances das duas escritoras - a moçambicana através da encenação literária e a brasileira com sua escrita sociológica - bem como os seus discursos, denunciam a dupla marginalização da mulher negra, procurando dar voz e visibilidade a esse sujeito que foi objetificado pela literatura de ambos os países e permaneceu em silêncio no cenário da tradição patriarcal. Suas escritas de resistência e insubordinação permitem a autoinscrição da mulher negra na literatura e na história, através do seu próprio ponto de vista, produzindo sua subjetividade, ou seja, "o trabalho por meio do qual as pessoas constroem e atribuem o significado à própria experiência e à própria identidade, constitui por si mesmo o argumento, o fim do discurso" (PORTELLI, Alessandro apud COSTA, 2007, p.2) .

A partir dessas escritas oriundas do ponto de vista das mulheres negras, de sua arte, estratégia e visão política, tornou-se possível enxergar a experiência feminina negra por uma perspectiva diversa da submissão ou da cristalização do estereótipo, reconhecendo e mantendo "uma tensão necessária entre igualdade e diferença, entre direitos individuais e identidades grupais, o que possibilita encontrarmos resultados melhores e mais democráticos" (SCOTT apud COSTA, 2007, p. 8), na luta pela insubordinação e resistência. Nessa trajetória, quem sabe, a utopia almejada por Evaristo, de que um dia, os povos cheguem a um momento de tradução em que as diferenças sejam vistas "com boa vontade", possa ser alcançada.

\section{Referências}

CANDIDO, Antonio. Literatura e Sociedade: Estudos de Teoria e história literária. $11^{\mathrm{a}}$ ed. Revista pelo autor. Rio de Janeiro: Ouro sobre Azul, 2010.

CHIZIANE, Paulina. Eu, mulher... Por uma nova visão do mundo. In: AFONSO, Ana Elisa de Santana (Coord.). Eu, mulher em Moçambique. República de Moçambique: Comissão Nacional para a UNESCO em Moçambique e Associação dos Escritores Moçambicanos: 1994.

CHIZIANE, Paulina. Niketche: uma história de poligamia. Lisboa: Editorial Caminho, $3^{\mathrm{a}}$ Ed., 2004.

COSTA. Renata Jesus da, Subjetividades femininas: mulheres negras sob o olhar de Carolina Maria de Jesus, Maria Conceição Evaristo e Paulina Chiziane. $152 \mathrm{f}$. Dissertação. Programa de Pós-Graduação em História Social. Pontifícia Universidade Católica de São Paulo, 2007.

DIOGO, Rosália Estelita Gregório. Paulina Chiziane: as diversas possibilidades de falar sobre o feminino. Scripta, Belo Horizonte, v. 14, n. 27, p. 173-182, $2^{0}$ sem. 2010.

EVARISTO, Conceição. Becos da memória. Belo Horizonte: Mazza, 2006.

EVARISTO, Conceição. Ponciá Vicêncio. Belo Horizonte: Mazza, 2003. 
GONÇALVES, Adelto. Passagens para o Índico: encontros brasileiros com a literatura moçambicana. Org. Chaves, Rita; Macedo, Tânia. Maputo: Marimbique, 2012.

LOFORTE, Ana Maria. Mulher, poder e tradição. In Outras Vozes, nº 5 , Novembro de 2003.

OLIVEIRA, Luiz Henrique Silva de. Escrivivência" em Becos da memória, de Conceição Evaristo. Estudos Feministas. Florianópolis, maio-agosto de 2009, p. 622.

SALGUEIRO. Maria Aparecida Andrade. Escritoras Negras Contemporâneas. Estudo de Narrativas - Estados Unidos e Brasil. Rio de Janeiro: Caetés, 2004, p. 110-111 e 12 